\title{
Integrating Economics In The K-12 Curriculum
}

George C. Georgiou, (E-mail: ggeorgiou@towson.edu), Towson University

\begin{abstract}
This is a multi-year study of the effects of integrating economics into the curriculum on the Maryland School Performance Assessment Program (MSPAP) economics outcome scores. The study was carried out using State summary and disaggregated data and summary data for each school system in the State of Maryland. The 1992, 1994, 1995, 1997 and 2000 MSPAP economics outcome scores for grades 3, 5, and 8, constitute the dependent variable for the study with the level of integration of economics in the curriculum and class size, being the main explanatory variables. Using comparative static analysis and regression analysis three questions were addressed. The first question asks how school systems with different levels of integration of economics in the curriculum compare to the State average. The second question asks how these groupings compare to each other. The third question employs regression analysis to determine the effect of economics instruction and class size on the economics test scores. Other explanatory variables considered include: wealth per capita, income per capita, expenditures per pupil, student enrollments, and the level of performance on the overall battery of MSPAP tests.
\end{abstract}

\subsection{Introduction}

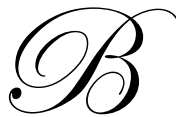

egun in 1964, the Developmental Economic Education Program (DEEP) has been the primary instrument for involving K-12 schools in economic education (Brenneke et al. 1988). Most studies have concluded that the DEEP process of in-service training and curriculum change can be effective in enhancing economic education (Buckles et al. 1984, Schober 1984) yet outcomes based data to support such claims remain elusive. The majority of states now require some form of economic education in public schools (Marlin 1991). While economists of all persuasions undoubtedly agree that universal economic literacy would be desirable, there appears to be substantial disagreement over what economic literacy is (Ferber 1999).

In an attempt to address this issue the National Council on Economic Education (NCEE) developed and published in 1997 the Voluntary National Content Standards in Economics for elementary and secondary schools. While this was a major achievement in the long and tortured history of pre-college economic education, it did not settle the on-going debate over national content standards in economics (Siegfried et al. 1997, 1998; Hanson 1998; Conrad 1998). The national content standards in economics acquire additional significance now that Congress has passed the No Child Left Behind education law (July 2002). This law mandates national annual outcome based testing for grades three through eight. These tests will measure mastery of specific concepts and requires the reporting of individual student scores.

Given the preoccupation of economics educators with college level instruction it is not surprising that many of the studies of high school economics concentrated on the effects of high school economics on the college principles of economics course (Lopus 1997; Brasfield et al. 1993). A number of studies, however, have attempted to determine the effectiveness of the teaching and learning of economics in high school (Myatt et al. 1990; Peterson 1992; Becker et al. 1990; Moomaw et al. 1995; Bosshard et al. 1990; Walstad 2001, 1994; Walstad et al. 2000, 1991; Harris et al. 1997; Becker et al. 1994). A much smaller number of studies have researched the determinants of

Readers with comments or questions are encouraged to contact the author via email. 
achievement of economics concepts by elementary and middle school students (Sosin et al. 1997; Bosshardt et al. 1994; Soper et al. 1991; Georgiou 1996).

The general objective of this study is to analyze the effect of the level of systematic integration of economics in the social studies curriculum on the Maryland School Performance Assessment Program (MSPAP) economics outcome scores. The MSPAP outcomes based testing program was in effect in Maryland from 1992-2002. This study has been undertaken using State summary and disaggregated data and summary data for each school system in the State of Maryland. The 1992, 1994, 1995, 1997, and 2000 MSPAP Outcome Scores for Economics (Social Studies Outcome \#4) for grades 3,5, and 8, constitute the dependent variable for the study with the level of systematic integration of economics in grades 1-8 and the number of Instructors Per 1000 Pupils, as the main explanatory variables. Other explanatory variables for economics outcome performance considered include: wealth per capita, expenditures per pupil, income per capita, percentage of students receiving Free/Reduced Price Meals; median household income; and the level of performance on the overall battery of MSPAP tests.

Three separate and progressively interesting questions are addressed. Having separated the individual school systems into those that have the instruction of economics integrated into the curriculum and those that do not, the first question asks how these groupings compare to the State average. The second question asks how these groupings compare to each other. This second question is of interest as it lends itself to more rigorous hypothesis testing. The third and vital question employs regression analysis to determine the effect of the level of economics integration in the curriculum and the effect of class size on economics test scores.

\subsection{Systematic Integration of Economics in the K-12 Social Studies Curriculum in Maryland}

Economics is not a subject that one normally thinks of as being taught at the pre-college level. While few would argue that it ranks in the first-tier category of subjects, i.e., reading, writing, and arithmetic; there are no justifiable arguments why economics should not be included in the second-tier of social science subjects that include, for example, history, government, geography, etc.

The driving force behind economics education in the State of Maryland is the Maryland Council on Economic Education (MCEE). MCEE is the only nonprofit, nonpartisan organization in Maryland that provides comprehensive support for economic education for elementary and secondary schools. This support focuses on enhanced teacher training, curriculum development, and instructional materials. An understanding of basic economic principles and our country's economy is vital to our youth in their roles as responsible voters, business owners, employees, and consumers. Moreover, MCEE's goal is to foster the teaching of important decision-making skills that these students will go on to apply in many aspects of their lives. It is precisely these types of skills that are embodied in the Maryland School Performance Assessment Program (MSPAP).

MCEE coordinates six affiliated Centers for Economic Education based at colleges and universities throughout Maryland. These Centers for Economic Education provide consultation for schools, educational agencies, and community organizations. They develop and distribute educational materials, improve instructional programs, and conduct research in economic education.

Currently, 18 out of Maryland's 24 public school systems are designated as Economics America school systems, having made a formal commitment with MCEE to build more economics into their curricula. While 18 of the 24 Maryland public school systems are designated as Economics America school systems, they are not automatically designated as having achieved a high level of integration of economics in their curricula based solely on their intentions. In fact, as of 2000, only three public school systems were considered by MCEE to have a 'High' - extensive, systematic integration of economics in grades 1-8, which was defined as integration in at least 4 grade levels. Fourteen public school systems were classified as "Middle' - with some integration of economics in grades 1-8, which was defined as 2-3 grade levels. Finally, seven public school systems were classified as 'Low' - which was defined as little or no integration of economics in grades 1-8. 
The inclusion of economics instruction in Maryland schools was voluntary until recently and varied from school system to school system. This began to change in 1982 when the State Board of Education passed the Social Studies bylaw, COMAR 13A.04.08, which included a mandate for teaching economics. This bylaw set forth seven broad social studies goals and respective sub goals. As an integral part of the new social studies mandate, Goal 2 states: Students will demonstrate an understanding of the historical development and current status of economic principles, institutions, and processes needed to be effective citizens, consumers, and workers in American society. Goal 2 focuses on the development of economic principles, institutions, and processes. This goal consists primarily of elements from the discipline of economics but also includes elements from the disciplines of history, political science, and geography. Through the study of Goal 2, the student should develop an understanding of the impact of scarcity on production and consumption, as well as facilitating rational decision making in the market place.

According to the Code of Maryland Regulations, local K-12 social studies programs in Maryland must encompass all of the goals and respective sub goals at the elementary level and again at the secondary level. In this regard the Maryland Council on Economic Education, through its Centers for Economic Education has used the Economics Goal 2 of the Social Studies: A Maryland Curricular Framework to assist Maryland social studies administrators and teachers in planning, developing, and integrating economics in the K-12 social studies programs. It is on the basis of this Curricular Framework that the level of systematic integration of economics in the curricula for each Maryland school system was evaluated for the purpose of the present study.

\subsection{Maryland School Performance Assessment Program (MSPAP): 1992-2002}

The keystone of the Maryland School Performance Program (MSPP), Maryland State Department of Education's (MSDE's) strategy to meet "Schools for Success" goals for the year 2000, was the process of setting standards against which schools are measured. Standards establish satisfactory and excellent performance levels in databased areas for schools to meet as they undertake school improvement to meet State and National goals. These are areas such as attendance, promotion rates, and assessed student knowledge on the Maryland School Performance Assessment Program (MSPAP).

The standards represent high expectations for school performance. Students are required to apply knowledge in and across content areas as they demonstrate their understanding of authentic reading selections and develop extended written responses to prompts. MSPAP test results are reported at grades 3,5, and 8, for reading, writing, language usage, mathematics, social studies, and science. Results are reported for each of these areas in terms of the mean, median, standard deviation, highest score, lowest score, number of students tested, and the number of students, and the percentage of students in four outcome score ranges: $0-25 \%, 26-50 \%, 51-75 \%$, and $76-100 \%$.

The social studies outcomes developed for grades 3, 5, and 8, are based on Social Studies: A Maryland Curricular Framework, as well as the reports and publications of the National Assessment of Education Progress (NAEP), National Council for the Social Studies (NCSS), the Bradley Commission, the National Governors' Association, and others involved in the ongoing task of designing social studies curriculum and instructional practices. The outcomes focus on the knowledge base required for understanding history and the social sciences, the process skills needed to analyze and apply that knowledge base, and the attitudes needed to use the knowledge and skills within a context of justice and democratic decision-making. The difference in grade level assessment is in the context and complexity of the tasks and questions. During its 10-year history, the MSPAP won acclaim in educational circles for encouraging critical thinking, as students worked in groups on part of the test and wrote answers to openended essay questions. However, it came under criticism for ranking schools, and not individual students, as well as keeping test questions secret. The MSPAP was abandoned in September 2002 in favor of a new Maryland School Assessment starting in March 2003. The new standardized test, which will rely on multiple-choice and essay questions, will be given annually to $3^{\text {rd }}, 5^{\text {th }}$, and $8^{\text {th }}$ graders and will provide individual scores. 
The social studies outcome score \#4: (Economics) is, of course, what is of interest to us and in this regard the relevant grade-level economics outcomes are the following:

\section{Grade Level 3: Economics}

1. Describe the relationship between economic wants and needs.

2. Describe the impact of economic specialization on the growth of communities.

3. Make decisions about available goods and services and understand the consequences of those decisions.

4. Examine the services financed through taxation.

5. Identify economic resources located within a community.

\section{Grade Level 5: Economics}

1. Describe the relationship between available resources and the production of goods and services.

2. Explain how the exchange of goods and services connects Maryland with the world.

3. Describe the relationship of supply and demand to the production and consumption of goods and services.

4. $\quad$ Examine examples of various types and uses of taxes.

5. Analyze historical and economic factors, which have contributed to the growth and development of Maryland's economy.

6. Analyze the effects of economic growth on the standards of living of individuals.

\section{Grade Level 8: Economics}

1. Using case studies, analyze the role of scarcity in economic decision-making.

2. Using case studies cite examples of economic interdependency among world communities.

3. Analyze the effects of supply and demand on the production of goods and services in historical and contemporary contexts.

4. Relate the development and implementation of taxation to given historical and economic conditions.

5. $\quad$ Compare the economic characteristics of Maryland with those of the U.S.

6. Analyze the impact of technological change and resource use in promoting economic growth in the U.S.

Students were first tested in social studies for the Maryland School Performance Assessment Program (MSPAP) in spring 1992 and in the spring of each subsequent year. The 1992, outcome scores, constitute the baseline-year data set and the 1994, 1995, 1997, and 2000 outcome scores, constitute the comparative static data set. The 1992, 1994, 1995, 1997 and MSPAP data sets provide disaggregation at the individual school system level and at the individual school level. No individual student results were provided because the tests were designed to provide data about school performance, not individual student performance.

\subsection{Statistical Analysis}

a. Effect of the Level of Integration of Economics in the Curriculum on the MSPAP Economics Outcome Scores for 1992, 1994, 1995, 1997, and 2000.

Table 1 summarizes the effect of the level of systematic integration of economics in the curriculum (grades 1-8) on the MSPAP economics outcome scores for 1992, 1994, 1995, 1997, and 2000 for grade levels 3, 5, and 8. Three levels of integration of economics (High, Middle, and Low) are presented, based on the number of grade levels for each school system in which economics is systematically integrated into the social studies curriculum. The school-system economics outcome scores for each level are then compared to the economics outcome scores for the whole state.

The State mean scores increased between 1992 and 2000 from 24.6 to 33.92 for grade 3, from 22.2 to 52.60 for grade 5, and from 31.9 to 47.35 for grade 8 . The higher the level of economics integration, the higher the test scores, with 'high' and 'middle' school systems scoring above the State mean while 'low' school systems scored be- 
low the State mean. These results are consistent for the 1992, 1994, 1995, 1997, and 2000 economics outcome scores and for all 3 grade levels. Consequently, at all three grade levels, and for all five years observed there is a positive correlation between the level of integration of economics in the social studies curriculum and the economics outcome scores, with the school systems with both 'high' levels of economics instruction (at least 4 grade levels) and 'middle' (at least 2-3 grade levels) scoring above the State mean while school systems with 'low' levels of economics instruction scoring consistently below the State mean.

\section{b. Hypothesis Testing}

The above statistical analysis compares the weighted average mean scores of school systems to the State mean scores based on the level of integration of economics instruction in the curriculum. The conclusion of this comparative static analysis is that the level of integration of economics in the curriculum is directly related to the level of economics outcome scores at grade levels 3,5 , and 8 .

In the second phase of the study hypothesis testing was employed to assess the statistical validity of integrating economics into the curriculum on the economics outcome scores. Hypothesis testing is used because the previous analysis employing comparative statics of weighted average mean scores might be flawed due to data deficiencies. It was therefore necessary to eliminate the possibility of sample bias and to establish a more scientifically valid correlation between the variables. At this stage of the analysis the three levels of economics integration: "High", "Middle" and "Low" are consolidated to two levels with the "High" category merged with the "Middle" level category. For the first test we are interested in determining whether the higher economics outcome scores of school systems that have integrated the instruction of economics into the curriculum (systematic integration of economics in the curriculum at 2 or more grade levels) are significantly higher than the economics outcome scores of school systems that have not integrated economics into their curriculum. For this we are using a test for the difference between population means with independent samples (known variances or large sample sizes) where we are testing the Null Hypothesis $\left(\mathrm{H}_{\mathrm{o}}\right)$ : school systems that have integrated economics instruction into the curriculum have lower or equal scores to school systems that have not integrated economics into the curriculum.

Table 1 MSPAP Economics Outcome Scores Grade Level: 3

\begin{tabular}{||c|c|c|c|c||}
\hline \multicolumn{2}{|c|}{} & \multicolumn{2}{c|}{ Level of Integration of Economics in the Curriculum } \\
\hline Year & State Mean & High & Middle & Low \\
\hline$' 92$ & 24.6 & 26.7 & 26.1 & 20.4 \\
\hline$' 94$ & 23.9 & 31.56 & 25.33 & 19.07 \\
\hline$' 95$ & 30.75 & 35.46 & 32.99 & 23.51 \\
\hline$' 97$ & 32.07 & 36.95 & 34.53 & 23.89 \\
\hline 00 & 33.92 & 37.18 & 35.31 & 29.91 \\
\hline
\end{tabular}

Grade Level: 5

\begin{tabular}{||c|c|c|c|c||}
\hline \multicolumn{2}{|c|}{} & \multicolumn{2}{|c|}{ Level on Integration of Economics in the Curriculum } \\
\hline Year & State Mean & High & Middle & Low \\
\hline 92 & 22.2 & 25.3 & 24.2 & 16.3 \\
\hline$' 94$ & 27.73 & 32.75 & 29.83 & 20.97 \\
\hline$' 95$ & 29.67 & 33.43 & 31.91 & 22.47 \\
\hline 99 & 37.55 & 42.79 & 39.75 & 30.15 \\
\hline 90 & 52.60 & 58.13 & 54.53 & 45.31 \\
\hline
\end{tabular}


Grade Level: 8

\begin{tabular}{||c|c|c|c|c||}
\hline \multicolumn{2}{|c|}{} & \multicolumn{2}{|c|}{ Level on Integration of Economics in the Curriculum } \\
\hline Year & State Mean & High & Middle & Low \\
\hline$' 92$ & 31.9 & 38.8 & 33.9 & 24.9 \\
\hline 94 & 37.59 & 46.65 & 39.35 & 30.78 \\
\hline$' 95$ & 37.66 & 44.70 & 39.79 & 29.94 \\
\hline 97 & 48.47 & 55.66 & 50.68 & 40.36 \\
\hline 90 & 47.35 & 52.64 & 49.26 & 39.47 \\
\hline
\end{tabular}

Note: $\quad$ High - extensive, systematic integration of economics in 1-8 (at least 4 grades)

Middle - some integration of economics in 1-8 (2-3 grades)

Low - little or no integration of economics in 1-8 (0-1 grades

Source: Maryland School Performance Assessment Program 1992, 1994, 1995, 1997, and 2000 Economics Outcome Scores, Maryland State Department of Education (MSDE)

$\mathrm{H}_{\mathrm{O}}: \quad \mu_{1} \leq \square \mu_{2}$

Against the Alternative Hypothesis $\left(\mathrm{H}_{\mathrm{A}}\right)$ : school systems that have integrated economics into the curriculum score higher than school systems that have not integrated economics into the curriculum.

$$
\mathrm{H}_{\mathrm{A}}: \quad \mu_{1}>\square \mu_{2}
$$

The decision rule is

$$
\begin{aligned}
& \text { Reject } \mathrm{H}_{\mathrm{O}} \quad \text { if } \\
& \frac{\overline{X_{1}}-\overline{X_{2}}}{\sqrt{\frac{\sigma_{1}^{2}}{n_{1}}+\frac{\sigma_{2}^{2}}{n_{2}}}} \succ Z_{a}
\end{aligned}
$$

The results of this test for years 1994, 1995, 1997, and 2000 are presented in Tables 2-4 where for all three grade levels the Null Hypothesis is rejected at the 1\% level of significance thereby supporting the Alternate Hypothesis that the integration of economics in the curriculum has a statistically significant impact on economics outcome scores. Taking this analysis one step further we determined, again at the $1 \%$ level of significance, that in 1994, school systems that had integrated economics education in the curriculum scored on average 6 points higher than other school systems both at grade level 5 and 8; and 4 points higher at grade level 3. In 1995, it was deter- 
mined, again at the $1 \%$ level of significance that school systems that had integrated economics in the curriculum scored on average 8 points higher than other school systems at grade level 8; and 6 points higher at grade level 3 and 5. In 1997, it was determined, again at the $1 \%$ level of significance that school systems that had integrated economics in the curriculum scored on average 9 points higher than other school systems at grade level 3, 5, and 8. Finally, in 2000, it was determined that school systems that had integrated economics in the curriculum scored 4, 8, and 7 points higher than other school systems at grade level 3,5, and 8, respectively. With mean economics outcome scores on the MSPAP often ranging in the twenties and thirties, a 4-9 point differential is significant.

Table 2

\begin{tabular}{|c|c|c|c|}
\hline \multicolumn{4}{|c|}{$\begin{array}{l}\text { MSPAP ECONOMICS OUTCOME SCORES } \\
\text { Grade Level: } 3\end{array}$} \\
\hline & & \multicolumn{2}{|c|}{ Integration of Economics in the Curriculum: } \\
\hline & & Yes & No \\
\hline \multirow{4}{*}{$\frac{\text { Mean }}{(\bar{X})}$} & ‘94 & 27.35 & 22.07 \\
\hline & ‘95 & 32.36 & 25.12 \\
\hline & ‘97 & 39.19 & 29.33 \\
\hline & '00 & 35.21 & 29.99 \\
\hline \multirow{4}{*}{$\begin{array}{l}\text { Variance } \\
\left(\sigma^{2}\right)\end{array}$} & ‘94 & 374.78 & 267.36 \\
\hline & ‘95 & 520.31 & 394.39 \\
\hline & ‘97 & 578.40 & 465.48 \\
\hline & ‘ 00 & 667.23 & 585.71 \\
\hline \multirow{4}{*}{$\begin{array}{l}\text { Standard } \\
\text { Deviation } \\
\left(\bullet \sigma^{2}\right)\end{array}$} & ‘94 & 19.36 & 16.35 \\
\hline & ‘95 & 22.81 & 19.86 \\
\hline & ‘97 & 24.05 & 21.58 \\
\hline & '00 & 25.83 & 24.20 \\
\hline \multirow{4}{*}{$\begin{array}{l}\text { Sample Size } \\
\text { (n) }\end{array}$} & ‘94 & 40258 & 13165 \\
\hline & ‘95 & 29348 & 9514 \\
\hline & ‘97 & 30541 & 9759 \\
\hline & ‘ 00 & 33116 & 9914 \\
\hline
\end{tabular}

$\mathrm{H}_{0}: \mu_{1} \leq \mu_{2}$

$\mathrm{H}_{\mathrm{A}}: \mu_{1}>\mu_{2}$

$$
Z=\frac{\overline{X_{1}}-\overline{X_{2}}}{\sqrt{\frac{\sigma_{1}^{2}}{n_{1}}+\frac{\sigma_{2}^{2}}{n_{2}}}}=\quad 30.6798^{\prime} * 29.7575^{\prime} * 38.2022^{\prime} * 18.5501^{*}>\mathrm{Z}_{0.01}=2.33
$$

Notes: * Significant at the $1 \%$ level

Yes $_{1}$ : School systems with systematic integration of economics in the curriculum at 2 or more grade levels.

$\mathrm{No}_{2}$ : School systems where integration of economics in the curriculum is at one or less grade levels. 
Table 3

\begin{tabular}{|c|c|c|c|}
\hline \multicolumn{4}{|c|}{$\begin{array}{l}\text { MSPAP ECONOMICS OUTCOME SCORES } \\
\text { Grade Level: } 5\end{array}$} \\
\hline & & \multicolumn{2}{|c|}{ Integration of Economics in the Curriculum: } \\
\hline & & Yes & No \\
\hline \multirow{4}{*}{$\frac{\text { Mean }}{(\bar{X})}$} & ‘94 & 31.9 & 24.3 \\
\hline & ‘95 & 32.21 & 24.99 \\
\hline & ‘97 & 39.46 & 29.69 \\
\hline & ${ }^{\prime} 00$ & 53.50 & 44.49 \\
\hline \multirow{4}{*}{$\begin{array}{l}\text { Variance } \\
\left(\sigma^{2}\right)\end{array}$} & '94 & 485.58 & 346.71 \\
\hline & '95 & 438.24 & 354.13 \\
\hline & ‘97 & 570.99 & 471.22 \\
\hline & '00 & 713.49 & 735.44 \\
\hline \multirow{4}{*}{$\begin{array}{l}\text { Standard } \\
\text { Deviation } \\
\left(\bullet \sigma^{2}\right)\end{array}$} & '94 & 22.04 & 18.62 \\
\hline & '95 & 20.96 & 18.82 \\
\hline & '97 & 23.90 & 21.71 \\
\hline & '00 & 26.71 & 27.12 \\
\hline \multirow{4}{*}{$\begin{array}{l}\text { Sample Size } \\
\text { (n) }\end{array}$} & '94 & 26993 & 8871 \\
\hline & '95 & 40520 & 12958 \\
\hline & ‘97 & 29026 & 9144 \\
\hline & ${ }^{\prime} 00$ & 31763 & 9086 \\
\hline
\end{tabular}

$\mathrm{H}_{\mathrm{o}}: \mu_{1} \leq \mu_{2}$

$\mathrm{H}_{\mathrm{A}}: \mu_{1}>\mu_{2}$

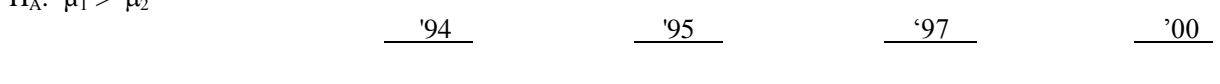

$$
\begin{aligned}
& Z=\frac{\overline{X_{1}}-\overline{X_{2}}}{\sqrt{\frac{\sigma_{1}^{2}}{n_{1}}+\frac{\sigma_{2}^{2}}{n_{2}}}}=\quad 31.81 * \quad 36.9498 * 36.6192 * 28.0162 * \quad>Z_{0.01}=2.33
\end{aligned}
$$

Notes: * Significant at the $1 \%$ level

Yes $_{1}$ : School systems with systematic integration of economics in the curriculum at 2 or more grade levels.

$\mathrm{No}_{2}$ : School systems where integration of economics in the curriculum is at one or less grade levels. 
Table 4

\begin{tabular}{|c|c|c|c|}
\hline \multicolumn{4}{|c|}{$\begin{array}{l}\text { MSPAP ECONOMICS OUTCOME SCORES } \\
\text { Grade Level: } 8\end{array}$} \\
\hline & & \multicolumn{2}{|c|}{ Integration of Economics in the Curriculum: } \\
\hline & & Yes & No \\
\hline \multirow{4}{*}{$(\bar{X})$} & '94 & 40.11 & 31.45 \\
\hline & '95 & 49.90 & 31.08 \\
\hline & '97 & 49.90 & 39.62 \\
\hline & ‘00 & 47.82 & 39.27 \\
\hline \multirow{4}{*}{$\begin{array}{l}\text { Variance } \\
\left(\sigma^{2}\right)\end{array}$} & ‘94 & 490.61 & 451.13 \\
\hline & '95 & 485.21 & 449.93 \\
\hline & ‘97 & 676.55 & 660.46 \\
\hline & '00 & 587.87 & 573.68 \\
\hline \multirow{4}{*}{$\begin{array}{l}\text { Standard } \\
\text { Deviation } \\
\left(\bullet \sigma^{2}\right)\end{array}$} & ‘94 & 22.15 & 21.24 \\
\hline & '95 & 22.03 & 22.21 \\
\hline & ‘97 & 26.01 & 25.70 \\
\hline & ‘00 & 24.25 & 23.95 \\
\hline \multirow{4}{*}{$\begin{array}{l}\text { Sample Size } \\
\text { (n) }\end{array}$} & '94 & 24382 & 7444 \\
\hline & '95 & 24760 & 7562 \\
\hline & '97 & 41451 & 12456 \\
\hline & '00 & 31118 & 8270 \\
\hline
\end{tabular}

$\mathrm{H}_{\mathrm{o}}: \mu_{1} \leq \mu_{2}$

$\mathrm{H}_{\mathrm{A}}: \mu_{1}>\mu_{2}$

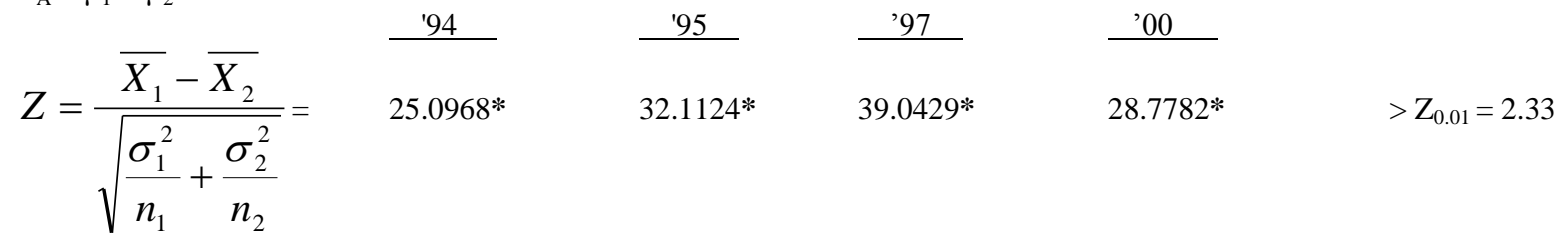

Notes: * Significant at the $1 \%$ level

Yes $_{1}$ : School systems with systematic integration of economics in the curriculum at 2 or more grade levels.

$\mathrm{No}_{2}$ : School systems where integration of economics in the curriculum is at one or less grade levels. 


\section{c. Regression Analysis}

Although the hypothesis testing undertaken in the previous section established a statistically significant correlation between economics outcome scores and the level of economics instruction it does not explain this relationship.

In the case of Maryland we are fortunate to have available possibly the only database of test scores where economics outcome scores are clearly specified. We have these scores for grades 3, 5, and 8 , for each of the 24 Maryland Public School Systems. It is apparent that the economics outcome scores are related to the overall academic performance of the school system. What we are interested in is whether the level of economics instruction has any differentiating impact on this relationship. To test this relationship we ran our first set of regressions with the economics outcome scores for grades 3, 5, and 8 (MSPAP3, MSPAP5, and MSPAP8) as the dependent variables; and the level of economics integration in the curriculum (EconInt) and the simple mean of the outcome scores of the six subcomponents of the overall MSPAP battery of tests for grades 3, 5, and 8, (MSPAP3T, MSPAP5T, and MSPAP8T, ) representing the overall academic performance of the individual school systems, as the independent variables. Given that there is a significant difference in the size of the 24 Maryland public school systems, Weighted Least Squares (WLS) Regression was employed which addresses this bias.

EconInt is a dummy variable for the level of economics integration in the curriculum with the value of 1 assigned to school systems that had integrated economics into the curricula in at least two or more grade levels, and the value of 0 assigned to all other school systems. The actual classification was done by the Maryland Council on Economic Education (MCEE), which considered not only the systematic integration of economics in the curricula but also the level of teacher training that had taken place.

As expected this first set of regressions (see Regression \#1, Table 5) presented a good fit with $\mathrm{F}$ values in all three cases significant at the $1 \%$ level. However, this was primarily due to the role of the overall performance of the respective school systems with the coefficients for MSPAP3T, MSPAP5T, and MSPAP8T characterized by high t-statistics that were statistically significant at the $1 \%$ level. In this first set of regressions, the level of economics integration, EconInt, was statistically insignificant at all grades levels.

Given that the overall performance of the school systems appears to be overwhelming any effect that economics instruction might be having on outcome scores, we dropped this variable for the second set of regression substituting class size in its place, i.e., Instructors Per 1000 Pupils. We have to be mindful of the number of explanatory variables employed given that we have only 24 school systems and we do not want to adversely impact our degrees of freedom. Again, this second set of regressions (see Regression \#2, Table 5) presented a good fit with F values in all three cases significant at the $1 \%$ level. More importantly, both EconInt and InstrPer1000 had high tstatistics that were statistically significant at the $1 \%$ level.

In an attempt to further investigate the effect of the level of integration of economics on outcomes scores, a revised classification of economics integration in the curriculum was introduced with the use of two dummy variables: where EconInt3 is a dummy variable for the level of economics integration 
TABLE 5

Determinants of Economics Outcome Scores, 2000

\begin{tabular}{|c|c|c|c|c|c|c|c|c|c|c|c|c|}
\hline \multicolumn{13}{|c|}{ Determinants of Economics Outcome Scores, 2000} \\
\hline & \multirow{2}{*}{\multicolumn{4}{|c|}{$\begin{array}{r}\text { Grade } 3 \\
\end{array}$}} & \multicolumn{4}{|c|}{$\begin{array}{r}\text { Grade } 5 \\
\end{array}$} & \multicolumn{4}{|c|}{ Grade 8} \\
\hline & \multicolumn{2}{|c|}{ Dependent Variable: Log MSPAP3 } & & & \multicolumn{4}{|c|}{ Dependent Variable: Log MSPAP5 } & \multicolumn{4}{|c|}{ Dependent Variable: Log MSPAP8 } \\
\hline & $\# 1$ & $\# 2$ & $\# 3$ & $\# 4$ & $\# 1$ & $\# 2$ & $\# 3$ & \#4 & $\# 1$ & $\# 2$ & $\# 3$ & $\# 4$ \\
\hline Constant & $\begin{array}{l}2.602 \\
(39.916)\end{array}$ & $\begin{array}{l}0.894 \\
(1.134)\end{array}$ & $\begin{array}{l}0.703 \\
(1.240)\end{array}$ & $\begin{array}{l}2.786 \\
(7.692)\end{array}$ & $\begin{array}{l}\mathbf{3 . 3 2 5} \\
(\mathbf{1 3 1 . 8 6 4 )}\end{array}$ & $\begin{array}{l}2.182 \\
(4.552)\end{array}$ & $\begin{array}{l}\mathbf{2 . 1 8 4} \\
(\mathbf{5 . 6 2 7})\end{array}$ & $\begin{array}{l}3.444 \\
(24.422)\end{array}$ & $\begin{array}{l}\mathbf{3 . 1 5 7} \\
(\mathbf{1 0 3 . 0 8 0})\end{array}$ & $\begin{array}{l}1.679 \\
(3.016)\end{array}$ & $\begin{array}{l}1.728 \\
(3.657)\end{array}$ & $\begin{array}{l}\mathbf{3 . 0 9 7} \\
\mathbf{( 1 6 . 3 2 5 )}\end{array}$ \\
\hline MSPAP3T & $\begin{array}{l}\text { 0.977 } \\
(\mathbf{1 3 . 3 5 8})\end{array}$ & & & $\begin{array}{l}1.008 \\
(10.568)\end{array}$ & & & & & & & & \\
\hline MSPAP5T & & & & & $\begin{array}{l}\mathbf{0 . 9 7 4} \\
(22.185)\end{array}$ & & & $\begin{array}{l}1.005 \\
(17.549)\end{array}$ & & & & \\
\hline MSPAP8T & & & & & & & & & $\begin{array}{l}\mathbf{0 . 9 5 9} \\
(19.553)\end{array}$ & & & $\begin{array}{l}0.946 \\
(14.889)\end{array}$ \\
\hline Econ Int & $\begin{array}{l}-0.61 \\
(0.837)\end{array}$ & $\begin{array}{l}0.524 \\
(2.956)\end{array}$ & & $\begin{array}{l}-0.089 \\
(-0.970)\end{array}$ & $\begin{array}{l}0.021 \\
(0.483)\end{array}$ & $\begin{array}{l}0.663 \\
(4.142)\end{array}$ & & $\begin{array}{l}-0.008 \\
(-0.142)\end{array}$ & $\begin{array}{l}0.043 \\
(0.885)\end{array}$ & $\begin{array}{l}0.686 \\
(4.415)\end{array}$ & & $\begin{array}{l}0.055 \\
(0.884)\end{array}$ \\
\hline Instr Per 1000 & & $\begin{array}{l}0.552 \\
(3.114)\end{array}$ & $\begin{array}{l}0.563 \\
\mathbf{( 4 . 4 0 4 )}\end{array}$ & $\begin{array}{l}-0.047 \\
(-0.519)\end{array}$ & & $\begin{array}{l}\mathbf{0 . 5 4 2} \\
(3.383)\end{array}$ & $\begin{array}{l}\mathbf{0 . 5 1 3} \\
(3.948)\end{array}$ & $\begin{array}{l}-0.045 \\
(-0.858)\end{array}$ & & $\begin{array}{l}\mathbf{0 . 5 5 0} \\
(3.542)\end{array}$ & $\begin{array}{l}\mathbf{0 . 5 0 9} \\
(3.848)\end{array}$ & $\begin{array}{l}0.18 \\
(0.317)\end{array}$ \\
\hline Econ Int 3 & & & $\begin{array}{l}0.797 \\
(4.508)\end{array}$ & & & & $\begin{array}{l}0.940 \\
(5.227)\end{array}$ & & & & $\begin{array}{l}\text { 0.978 } \\
(5.345)\end{array}$ & \\
\hline Econ Int 4 & & & $\begin{array}{l}1.049 \\
(5.873)\end{array}$ & & & & $\begin{array}{l}1.037 \\
(5.716)\end{array}$ & & & & $\begin{array}{l}0.988 \\
(5.349)\end{array}$ & \\
\hline Adjusted $\mathrm{R}^{2}$ & 0.899 & 0.345 & 0.644 & 0.896 & 0.966 & 0.466 & 0.632 & 0.966 & 0.958 & 0.497 & 0.619 & 0.956 \\
\hline \# Observations & 24 & 24 & 24 & 24 & 24 & 24 & 24 & 24 & 24 & 24 & 24 & 24 \\
\hline
\end{tabular}

WLS $=$ Weighted Least Squares Regression $=$ Weighted by Enrollment

Notes: $\mathrm{t}$ statistic in parenthesis

Bold denotes significance at the $1 \%$ level 
in the curriculum with the value of 1 assigned to school systems that are classified as 'Middle' (2-3 grades of economics integration, and the value of 0 assigned to all other school systems; and EconInt 4 is a dummy variable for the level of economics integration in the curriculum with the value of 1 assigned to school systems that are classified as 'High' (at least 4 grades of economics integration), and the value of 0 assigned to all other school systems.

This third set of regressions (see Regression \#3, Table 5) also gives us a good fit with statistically significant $\mathrm{F}$ values and with all the explanatory variables significant at the $1 \%$ level with EconInt 4 having higher coefficients and t-statistics than EconInt 3 as expected. These results provide further evidence that greater levels of economics instruction are positively related to higher outcome scores with school systems with 'High' levels of economics integration performing better than school systems with 'Middle' levels of economics integration in the curriculum.

In a final set of regressions we again introduced the overall performance of school systems (MSPAP3T, MSPAP5T, and MSPAP8T), into the equation together with both the level of economic integration (EconInt) and class size (InstrPer1000). Once again, as expected the level of overall performance of school systems overwhelmed both the level of economic integration and class size with only the former being statistically significant, again at the $1 \%$ level.

\subsection{Conclusion}

This study constitutes the latest phase of a multi-year study of the effects of integrating economics into the social studies curriculum, on the Maryland School Performance Assessment Program (MSPAP) economics outcome scores. Using comparative static analysis and finally regression analysis; three questions were addressed. The first question asks how school systems with different levels of integration of economics in the curriculum compare to the State average. The second question asks how these groupings compare to each other. The third question employs regression analysis to determine the effect of the level of economics integration in the curriculum and class size on economics test scores.

Initially, three levels of integration of economics in the social studies curriculum were identified for the 24 Maryland school systems for grades 3, 5, and 8: "High" (at least 4 grade levels of economics instruction), "Middle" (at least 2-3 grade levels), and "Low" (one or less grade levels). At all 3 grade levels, a positive correlation was observed between the level of integration of economics in the social studies curriculum and the economics outcome scores of the 1992, 1994, 1995, 1997, and 2000 MSPAP, with school systems with 'High' and 'Middle' levels of economics instruction scoring above the State mean and school systems with 'Low' levels of economics instruction scoring consistently below the State mean.

Turning our attention to the second question addressed by our study, namely, how do the school systems that have integrated economics in the curriculum compare to school systems that have not, we tested the Null Hypothesis: that school systems that have integrated economics instruction into the curriculum have lower or equal scores to school systems that have not integrated economics into the curriculum, against the Alternative Hypothesis: that school systems that have integrated economics into the curriculum will score higher than those that have not. The Null Hypothesis was rejected at all 3 grade levels at the $1 \%$ level of significance. That is, economics education does have a significant impact on economics outcome scores. Namely, a 6 to 9 point difference at grades 5 and 8 , and a 4 to 9 point difference at grade 3 , all at the $1 \%$ level of significance.

Finally, and most importantly we analyzed the impact of integrating economics into the curriculum on economics outcome scores using regression analysis in an attempt to shed light on the nature of the relationship between the variables. Four sets of regressions were presented for grades 3, 5, and 8 . All these regression equations gave a good fit with significant F-Values and significant t-statistics for the level of economic integration in the curriculum and class size. Both explanatory variables were significant at the $1 \%$ level. This result was not immediately obvious as it was masked by the overwhelming influence of the overall academic strength of the respective school systems. In that regard other popular explanatory variables for academic performance such as: expenditures per pupil, income per capita, wealth per pupil, and income per capita, all proved to be statistically insignificant. 


\section{References}

1. Becker, William; Greene, William; and Rosen, Sherwin. 1990. Research on High School Economic Education. Journal of Economic Education. 21.3: 229-245.

2. Becker, William; Greene, William; Rosen, Sherwin. 1994. Research on High School Economics in the United States: Further Considerations. An International Perspective on Economic Education. 89-108. Dordrecht and Boston: Kluwer Academic.

3. Bosshardt, William, and Watts, Michael. 1990. Instructor Effects and Their Determinants in Precollege Economic Education. Journal of Economic Education. 21.3: 265-276.

4. Bosshardt, William, and Watts, Michael. 1994. Instructor Effects in Economics in Elementary and Junior High Schools. Journal of Economic Education. 25.3: 195-211.

5. Brightman, Harvey J. 1986. Statistics in Plain English. South-Western Publishing Co. Cincinnati.

6. Brenneke, Judith S, Highsmith, Robert J., Soper, John C., Walstad, William B., and Watts, Michael W. 1998. A Research and Evaluation Agenda for DEEP and Precollege Economic Education. Journal of Economic Education. 19.1: 5-13.

7. Brasfield, David W.; Harrison, Dannie E.; McCoy, James P. 1993. The Impact of High School Economics on the College Principles of Economics Course. Journal of Economic Education. 24.2: 99-111.

8. Buckles, Stephen and V. Freeman. 1984. A Longitudinal Analysis of a Developmental Economics Education Program. Journal of Economic Education. 15.1: 5-10.

9. Conrad, Cecilia A. 1998. National Standards or Economic Imperialism? Journal of Economic Education. 29.2: 167-69.

10. Council on Economic Education in Maryland, Annual Reports 1990-2001, Towson University, Towson, Maryland.

11. Ferber, Marianne A. 1999. Guidelines for Pre-College Economics Education: A Critique. Feminist Economics. 5.3:135-42.

12. Georgiou, George. 1996. Economics in the Pre-College Curriculum. International Advances in Economic Research. 2.1:64-75

13. Hansen, W. Lee. 1998. Principles-Based Standards: On the Voluntary National Content Standard in Economics. Journal of Economic Education. 29.2: 150-56.

14. Harris, Robert B. and Kerby, William C. 1997. Statewide Performance Assessment as a Complement to Multiple-Choice Testing in High School Economics. Journal of Economic Education. 28.2: 122-34.

15. Lopus, Jane S. 1997. Effects of the High School Economics Curriculum on Learning in the College Principles Class. Journal of Economic Education. 28.2: 143-53.

16. Marlin, Jr., James W. 1991. State Mandated Economic Education, Teacher Attitudes, and Student Learning. Journal of Economic Education. 22.1: 5-14.

17. Maryland State Department of Education. 1992. 1993. 1994. 1995. 1997. 2000. Maryland School Performance Report: State and School Systems. Baltimore, Maryland.

18. Maryland State Department of Education. 1982. Social Studies: A Maryland Curricular Framework. Baltimore, Maryland.

19. Moomaw, Ronald L. and Yusof, Mahzan. 1995. The Determinants of High School Test Scores in Oklahoma. Journal of Economics. 21.2: 77-85.

20. Myatt, Anthony and Waddell, Charles. 1990. An Approach to Testing the Effectiveness of the Teaching and Learning of Economics in High School. Journal of Economic Education. 21.3: 355-363.

21. Newbold, Paul. 1984. Statistics For Business And Economics. Prentice-Hall, Inc., Englewood Cliffs.

22. Peterson, Norris A. 1992. The High School Economics Course and Its Impact on Economic Knowledge. Journal of Economic Education. 23.1: 5-16.

23. Securities Industry Foundation for Economic Education. 1993. The Stock Market Game Players Manual. New York.

24. Siegfried, John J. and Bonnie T. Meszaros. 1997. National Voluntary Content Standards for Pre-College Economics Education. American Economic Review. 87.2: 247-53.

25. Siegfried, John J. and Bonnie T. Meszaros. 1998. Voluntary Economics Content Standards for America's Schools: Rationale and Development. Journal of Economic Education. 29.2: 139-49.

26. Smith, Gary. 1988. Statistical Reasoning (Second Edition). Allyn and Bacon, Inc., Boston. 
27. Schober, Howard M. 1984. The Effects of Inservice Training on Participating Teachers and Students in Their Economics Classes. Journal of Economic Education. 15.4: 282-296.

28. Soper, John C. and Walstad, William B. 1991. Economic Knowledge in Junior High and Elementary Schools. Effective Economic Education in the Schools. NEA Professional Library. Reference and Resource Series Washington, D.C.; National Education Association; New York: Joint Council on Economic Education.

29. Sosin, Kim; Dick, James; Reiser, Mary Lynn. 1997. Determinants of Achievement of Economics Concepts by Elementary School Students. Journal of Economic Education. 28.2: 100-121.

30. Walstad, William B. 2001. Economic Education in U.S. High Schools. Journal of Economic Perspectives. 15.3:195-210.

31. Walstad, William B. 1994. An Assessment of Economics Instruction in American High Schools. An International Perspective on Economic Education. Dordrecht and Boston: Kluwer Academic.

32. Walstad, William B. and Rebeck, Ken; 2000. The Status of Economics in the High School Curriculum. Journal of Economic Education. 31.1: 95-101.

33. Walstad, William B. and Soper, John C. 1991. Economic Literacy in Senior High Schools. Effective Economic Education in the Schools. 99-116. NEA Professional Library. Reference and Resource Series Washington, D.C.: National Education Association; New York; Joint Council on Economic Education.

\section{Notes}

